\title{
Evaluation of culture media and conditions of Amazonian filamentous fungi in an antimicrobial screening program
}

\author{
Avaliação de meios e condições de cultivo de fungos fillamentosos Amazônicos em um programa de \\ triagem de antimicrobianos \\ Evaluacíon de médios de cultivo y condiciones de hongos filamentosos Amazónicos em um
} programa de tamizaje antimicrobiano

Monique Antunes Negreiros ORCID: https://orcid.org/0000-0001-6428-1460 Federal University of the Amazons, Brazil E-mail: moniqueantunes39@gmail.com Milthes Viana Guedes ORCID: https://orcid.org/0000-0001-9182-3720 Federal University of the Amazons, Brazil E-mail: milthesguedes@gmail.com

Thaís Karoline de Sousa Rodrigues ORCID: https://orcid.org/0000-0002-7982-7371

Federal University of the Amazons, Brazil E-mail: thaiskarolyne2522@gmail.com

Beatriz Rebelo Rodrigues

ORCID: https://orcid.org/0000-0003-0629-2852 Federal University of the Amazons, Brazil E-mail: brebelo647@gmail.com Andria Lopes Cruz ORCID: https://orcid.org/0000-0003-0745-5203 Federal University of the Amazons, Brazil E-mail: andriapcruz@gmail.com Priscila Dallé da Rosa ORCID: https://orcid.org/0000-0002-2187-4319 Federal University of Rio Grande do Sul, Brazil E-mail: pri_dr_rosa@hotmail.com

Saulo Fernandes de Andrade ORCID: https://orcid.org/0000-0003-2873-7939 Federal University of Rio Grande do Sul, Brazil E-mail: saulo.fernandes@ufrgs.br

Alexandre Meneghello Fuentefria ORCID: https://orcid.org/0000-0003-2979-4417 Federal University of Rio Grande do Sul, Brazil E-mail: alexandre.fuentefria@ufrgs.br Ranieri Campos

ORCID: https://orcid.org/0000-0002-9413-4215

Federal University of the Amazons, Brazil E-mail: raniericampos1980@gmail.com

Maxwel Adriano Abegg

ORCID: https://orcid.org/0000-0002-0328-1122

Federal University of the Amazons, Brazil E-mail: maxabegg@gmail.com

\begin{abstract}
The rediscovery of bioactive compounds is a problem within natural product screening programs, because the chemical-genetic diversity of fungi is little explored and the standardization of cultivation conditions that allow obtaining new actives is critical in such programs. In this work, the impact of two solid mediums (rice and oats), a liquid medium (Czapeck broth) and different fermentation conditions were evaluated in order to explore new metabolic routes. Twelve filamentous fungi from Amazonian environments were used. UV-Vis spectrophotometry estimated the complexity of the extracts produced. The antimicrobial activity of the extracts was evaluated against an isolate of each Escherichia coli strain, Salmonella sp. and Staphylococcus aureus. Solid media proved to be more promising, as they allowed a wider range of active metabolites to be obtained. The oat medium provided a greater variety of metabolites, but due to the great complexity of the extracts obtained, the separation procedures were
\end{abstract}


considerably more complex than for rice. Together, the rice culture medium and the use of 39 days of fermentation proved to be more promising conditions than the liquid medium normally used in screening programs in Brazil. The cultivation of Penicillium maximae (isolated for the second time in Brazilian territory) in solid medium provided the production of active fractions against $E$. coli in bioautography. In this study, it was observed that different fermentation conditions in solid culture are considerably promising in the search for bioactive natural products.

Keywords: Antimicrobials; Fungi; Bioactive compounds; Cultivation means; Cultivation conditions; Secondary metabolites.

\section{Resumo}

A redescoberta de compostos bioativos é um problema dentro dos programas de triagem de produtos naturais, isto porque a diversidade químico-genética dos fungos é pouco explorada e a padronização das condições de cultivo que permitam a obtenção de novos ativos é crítica em tais programas. Neste trabalho, avaliou-se o impacto de dois meios sólidos (arroz e aveia), um meio líquido (caldo Czapeck) e diferentes condições de fermentação, com objetivo de explorar novas rotas metabólicas. Foram utilizados 12 fungos filamentosos de ambientes Amazônicos. A espectrofotometria UV-Vis estimou a complexidade dos extratos produzidos. A atividade antimicrobiana dos extratos foi avaliada contra um isolado de cada cepa de Escherichia coli, Salmonella sp. e Staphylococcus aureus. Os meios sólidos mostraram-se mais promissores, pois permitiram a obtenção de uma gama maior de metabólitos ativos. O meio aveia proporcionou maior variedade de metabólitos, mas devido à grande complexidade dos extratos obtidos, os procedimentos de separação foram consideravelmente mais complexos do que o arroz. Em conjunto, o meio de cultivo em arroz e o uso de 39 dias de fermentação mostraram-se condições mais promissoras do que o meio líquido normalmente empregado em programas de triagem no Brasil. O cultivo de Penicillium maximae (isolado pela segunda vez em território brasileiro) em meio sólido proporcionou a produção de frações ativas contra $E$. coli em bioautografia. Neste estudo, observou-se que diferentes condições de fermentação em cultivo sólido são considerávelmente promissoras na busca de produtos naturais bioativos.

Palavras-chave: Antimicrobianos; Fungos; Compostos bioativos; Meios de cultivo; Condições de cultivo; Metabólitos secundários.

\section{Resumen}

El redescubrimiento de compuestos bioactivos es un problema dentro de los programas de cribado de productos naturales, debido a que la diversidad químico-genética de los hongos está poco explorada y la estandarización de las condiciones de cultivo que permitan la obtención de nuevos activos es fundamental en dichos programas. En este trabajo se evaluó el impacto de dos medios sólidos (arroz y avena), un medio líquido (caldo Czapeck) y diferentes condiciones de fermentación con el fin de explorar nuevas rutas metabólicas. Se utilizaron doce hongos filamentosos de ambientes amazónicos. La espectrofotometría UV-Vis estimó la complejidad de los extractos producidos. La actividad antimicrobiana de los extractos se evaluó frente a un aislado de cada cepa de Escherichia coli, Salmonella sp. y Staphylococcus aureus. Los medios sólidos demostraron ser más prometedores, ya que permitieron obtener una gama más amplia de metabolitos activos. El medio de avena proporcionó una mayor variedad de metabolitos, pero debido a la gran complejidad de los extractos obtenidos, los procedimientos de separación fueron considerablemente más complejos que para el arroz. Juntos, el medio de cultivo de arroz y el uso de 39 días de fermentación resultaron ser condiciones más prometedoras que el medio líquido normalmente utilizado en los programas de detección en Brasil. El cultivo de Penicillium maximae (aislado por segunda vez en territorio brasileño) en medio sólido proporcionó la producción de fracciones activas contra E. coli en bioautografía. En este estudio se observó que diferentes condiciones de fermentación en cultivo sólido son considerablemente prometedoras en la búsqueda de productos naturales bioactivos.

Palabras clave: Antimicrobianos; Hongos; Compuestos bioactivos; Medios de cultivo; Condiciones de cultivo; Metabolitos secundarios.

\section{Introduction}

Compounds isolated from biological sources represent the vast majority of drugs approved for clinical use, especially for cancer and infectious diseases (Dayanidhi et al., 2021; Atanasov et al., 2021). Approximately one quarter of the therapeutic compounds were isolated from fungi (Berdy, 2012). These microorganisms synthesize compounds that may be the key to solving emerging public health problems (Raghava Rao, Mani, Satyanarayana \& Raghava, 2017). However, according to Palma Esposito et al. (2021) certain cultivation conditions do not always favor the expression of cryptic genes (genes silenced under a standard cultivation condition), and the rediscovery of bioactive molecules is a problem faced by natural product laboratories (Pan, Bai, Chen, Zhang \& Wang, 2019). 
Variation of cultivation parameters, an approach often known as OSMAC (One Strain Many Compounds) (Loffy et al., 2021), can have significant impacts on the quantity and diversity of secondary metabolites produced (Zutz et al., 2016). However, in an antimicrobial screening program in which a large number of filamentous fungi are to be screened, the OSMAC approach is not always viable, so the pursuit of a culture medium and condition that will allow more efficient production of new Antimicrobials become a necessity (VanderMolen, Raja, El-Elimat \& Oberlies, 2013).

Evaluating different fermentation parameters such as medium composition, aeration rate, temperature and $\mathrm{pH}$ change can also be a laborious process, so in this study we chose to analyze the impact of modifications on two critical parameters in the process. fermentatives: the culture media and the fermentation time. Furthermore, the use of conditions that impose stress on the microorganism may favor the detection and isolation of a more diverse range of bioactive compounds, with solid fermentation being more associated with metabolic stress of cultivated fungi than fermentation in broth (VanderMolen et al., 2013).

Thus, this study aimed to optimize the culture media and time in order to induce alternative metabolic pathways to obtain new compounds within an antimicrobial screening program.

\section{Methodology}

The study was carried out with twelve filamentous fungi, six isolateds from different types of Amazonian soil (unpublished data) and six air isolates (anemophiles) in a previous study (Cruz, Souza de \& Abegg, 2019). These fungi were pre-selected for preliminary antimicrobial activity results (data not shown). Soil fungi were obtained by the use of two selective media with the intention of isolating low abundance microorganisms: HSUC and starch milk agar, according to Du $e t$ al. (2012).

\subsection{Identification of Filamentous Fungi}

The twelve isolates were identified by morphological techniques (macro and microscopic) (Gomes et al., 2015). Of these twelve isolates, five isolates with marked antimicrobial potential were identified by sequencing the internal transcribed spacer in the ITS regions (ITS1- 5.8S-ITS2 of the rDNA gene), according to the protocol of Tonial et al. (2015), the sequences being compared using the GenBank platform.

\subsection{Pilot Scale Cultivation}

The twelve isolates were grown on a pilot scale under two fermentation conditions, solid (rice and oats) and liquid (Czapeck broth). The media were prepared according to VanderMolen et al. (2013).

\subsubsection{Cultivation in Solid Medium}

The fungi were grown on $2 \%$ malt extract agar at $28^{\circ} \mathrm{C}$ for ten days. Ten plugs $(7 \mathrm{~mm})$ from the culture plates were transferred to $15 \mathrm{~mL}$ of YESD broth ( $20 \mathrm{~g}$ soy peptone, $20 \mathrm{~g}$ dextrose, $5 \mathrm{~g}$ yeast extract, $1 \mathrm{~L} \mathrm{H} 2 \mathrm{O}$ ) and this broth was incubated for 5 days with shaking. orbit at $110 \mathrm{rpm}$ and room temperature. The pre-fermentation broth containing the mycelial mass was poured onto the solid media (rice and oats), which were cultivated under static condition for 11 and 31 days. To obtain the extracts, $50 \mathrm{~mL}$ of methanol was added to each culture, the material was macerated and subjected to orbital agitation at 100 rpm for 24 hours. The cultures were filtered, the mycelia being discarded and the extracts concentrated in rotary evaporator (VanderMolen et al., 2013). 


\subsubsection{Liquid Culture}

The fungi were grown on $2 \%$ malt extract agar at $28^{\circ} \mathrm{C}$ for 28 days. Ten plugs $(7 \mathrm{~mm})$ were transferred to $250 \mathrm{ml}$ Czapeck broth. The cultures were fermented under orbital agitation at $100 \mathrm{rpm}$ for 14 and 21 days at room temperature. To obtain crude extracts, $250 \mathrm{~mL}$ of methanol was added to the liquid cultures. Extraction occurred under orbital agitation at 100 rpm for 24 hours and the extracts were concentrated by rotary evaporator.

\subsection{Antimicrobial Activity of Crude Extracts}

\subsubsection{Test Microorganisms}

The target bacteria were: Escherichia coli ATCC 25922, Salmonella sp. (laboratory strain) and Staphylococcus aureus INCQS 0324. The strains were stored in a freezer at $-20^{\circ} \mathrm{C}$ in Luria Bertani broth (LB) (g / L composition: 29 hydrolyzed enzymatic casein $10.0 \mathrm{~g}$, yeast extract $5.0 \mathrm{~g}$, sodium chloride $10.0 \mathrm{~g}$, pH: $7.5 \pm 0.2$ ) added with $20 \%$ glycerol.

\subsubsection{Antimicrobial Activity Test}

Dry methanolic extracts were resuspended $(200 \mathrm{mg} / \mathrm{mL})$ in sterile distilled water and tested for antimicrobial activity by the Spot technique (Fleming, Etchells, \& Costilow,1975). Standard suspensions of the target bacteria were produced, OD600nm $=0.02$ for E. coli and Salmonella sp. and 0.05 for Staphylococcus aureus. The suspensions were homogeneously distributed on the surface of $90 \mathrm{~mm}$ Mueller Hinton (AMH) agar plates, pending the drying of the agar surface in a biological safety cabinet. Subsequently, $10 \mu \mathrm{L}$ of crude extracts were pipetted at three equidistant points per plate. The test was performed in triplicate and sterile distilled water was used as negative control. Results were interpreted based on the measurement of inhibition halos after 24 hours of incubation at $37^{\circ} \mathrm{C}$.

\subsection{Breakdown of Active Extracts}

The raw extracts produced in pilot scale were partitioned liquid-liquid, repeating the extraction process three times for each solvent. Solvents in increasing order of polarity (Hexane $\mathrm{C} 6 \mathrm{H} 14$, Chloroform $\mathrm{CHCl} 3$ and Ethyl Acetate $\mathrm{C} 4 \mathrm{H} 8 \mathrm{O} 2$ ) were used in a 1: 1 (v / v) ratio (Etame et al., 2019). Four fractions were generated: Hexane Fraction (FH), Chloroform Fraction (FC), Ethyl Acetate Fraction (FA) and Remnant Fraction (FR). The obtained fractions were rotary evaporated and their masses determined. Fraction yield was calculated in grams and fractions were tested for antimicrobial activity by the agar diffusion method (Silveira, Olea, Mesquita, Cruz \& Mendes, 2009).

\subsection{Analysis of the Remaining Fraction Complexity}

Scanning analyzes were performed on a UV-Vis Spectrophotometer (Gold Spectrum Lab. - UV-5200) ( $\lambda 250-600 \mathrm{~nm}$ ) as a preliminary analysis of the complexity of the Remaining Fractions obtained on a pilot scale. Data were processed in Origin Software 2017 (Originlab).

\subsection{Large Scale Solid Fermentation}

Ten filamentous fungi were grown on $2 \%$ malt extract agar (2\% MEA) for ten days. Twenty plugs $(7 \mathrm{~mm})$ from the cultures were transferred to $30 \mathrm{~mL}$ of YESD broth. Pre-fermentation broths were grown under orbital agitation at $100 \mathrm{rpm}$ for five days at room temperature.

The pre-fermented material was transferred to $2 \mathrm{~L}$ flasks containing oat solid medium $(400 \mathrm{~g}$ oats and $300 \mathrm{~mL}$ distilled water). This medium was chosen because of a seemingly larger range of metabolites generated at the pilot scale. 
The solid medium was then homogenized by maceration and cultivation followed for 39 days in static condition and room temperature. For extraction, $1.5 \mathrm{~L}$ of methanol was added to each flask and extraction occurred for 12 hours under orbital agitation at $120 \mathrm{rpm}$. To confirm the antimicrobial activity of the large-scale crops the extracts were subjected to Spot activity testing (Fleming, Etchells, \& Costilow,1975).

\subsection{Partial Purification of Active Compounds}

Two extracts (HSUC-6 and IS-9) produced from the cultivation of fungi Penicillium maximae and Fusarium oxysporum on a large scale were submitted to purification processes. These extracts were initially partitioned liquid-liquid three times using solvents in increasing order of polarity: Hexane $(\mathrm{C} 6 \mathrm{H} 14)$, Chloroform $(\mathrm{CHCl3})$ and Ethyl Acetate (C4H8O2) in a 1:1 ratio (v/v) according Etame et al. (2019). The fractions with higher polarity obtained after partition were submitted to Column Chromatography (CC) by Merck®60 (0.063-0.200 mm).

The IS-9 ethyl acetate fraction and the remaining HSUC-6 fraction obtained after Column Chromatography, were treated with the chloroform: methanol and ethyl acetate: methanol systems, respectively, in $100 \mathrm{~mL}$ portions, with a $10 \%$ increment of methanol each eluted portion (Sanchez \& Wang, 2012). Individually collected fractions from the column were analyzed by Thin Layer Chromatography (CCD) using standard silica-coated chromatographic plates (Merck®) (Azerang et al., 2019). The fractions were applied to the chromatoplates, eluted in chloroform: ethyl acetate (2: 8) and observed in UV light chamber $(\lambda 250 \mathrm{~nm}$ and $350 \mathrm{~nm}$ ). From the isolated bands Rf (Retention Factor) values were calculated and fractions with similar band patterns were pooled.

\subsection{Fraction Antimicrobial Activity}

The antimicrobial activity of semi-purified fractions was evaluated by bioautography technique (Dewanjee, Gangopadhyay, Bhattacharya, Khanra \& Dua, 2015). The fractions were chromatographed on chromatographic plates (Merck $®)$ with chloroform: ethyl acetate $(2: 8 ; \mathrm{v} / \mathrm{v})$ elution system. The plates were dried to full evaporation of the solvents and analyzed in a UV light chamber $(\lambda 300 \mathrm{~nm})$ to determine the Rf values. Suspensions of the target microorganisms (OD600nm 0.02 for E. coli and Salmonella sp. and 0.05 for S. aureus) were homogeneously distributed and dried on the surface of AMH plates. The eluted chromatoplates were applied upside down on the inoculated surface and kept in contact with the target bacteria for 3 hours. Then the chromatoplates were removed and the plates incubated for 24 hours at $37^{\circ} \mathrm{C}$. The results were interpreted based on the observation of inhibition halos in the previously observed bands.

The minimum inhibitory concentration (MIC) of the fractions of interest was determined by 96 well plate microdilution assay (Noumi et al., 2018). The E. coli test strain was grown at $37^{\circ} \mathrm{C}$ overnight and a suspension adjusted to OD600nm $=0.02$. Semi-purified fractions were resuspended in 10\% DMSO and tested at concentrations of 500 to $3.9 \mu \mathrm{g} / \mathrm{mL}$. Inhibitory activity was evidenced with the aid of the rezasurine colorimetric indicator $(0.01 \%)$.

\subsection{Statistical Analysis}

Analyzes were performed using Biostat (AnalystSoft) software using one - way ANOVA and Tukey 's test. Data were considered significantly different when $\mathrm{p}<0.05$. Pearson's coefficient $(\rho)$ was used to calculate the correlation between the evaluated data. 


\section{Results and Discussion}

\subsection{Identification of Filamentous Fungi}

The twelve isolates were categorized into four genera: Aspergillus sp., Penicillium sp., Curvularia sp. and Fusarium sp. (Table 1). Marked active fungi in preliminary studies were identified at molecular level as representative of the species: Penicillium maximae, Penicillium rolfsii, Aspergillus ochraceus, Aspergillus melleus and Fusarium oxysporum (Table 1).

In the literature, there are reports that the mentioned species have antimicrobial potential (Rani, Sharma, Chaturvedi \& Yadav, 2017; Scopel et al., 2017), antifungal (Awaad, Nabilah \& Zain, 2012) and anticancer (Katoch, Phull, Vaid \& Singh, 2017; Scopel et al., 2017). However, P. maximae deserves attention because it is a recently isolated and still little explored species. P. maximae was isolated in Brazil by Scopel et al. (2017) from marine sponges, producing compound called arvoredol, which has anti-biofilm properties against Staphylococcus epidermidis and active against colorectal carcinoma cells. However, there are no reports of isolation of soil samples in Brazil.

Table 1. Identification of filamentous fungi incorporated into the collection according to source and isolation medium.

\begin{tabular}{ccccc}
\hline Code & $\begin{array}{c}\text { Collection } \\
\text { Source }\end{array}$ & $\begin{array}{c}\text { Isolation } \\
\text { Substrate }\end{array}$ & $\begin{array}{c}\text { Strain } \\
\text { Identification* }\end{array}$ & Accession Number \\
\hline HSUC-6 & Soil & HSUC & Penicillium maximae* $^{*}$ & MN782328 \\
IS-9 & Soil & SMA & Fusarium oxysporum* & MN782327 \\
IS-6 & Soil & SMA & Aspergillus sp. & - \\
IS-7 & Soil & SMA & Aspergillus sp. & - \\
TPP1.1 & Soil & SMA & Aspergillus sp. & - \\
TPP1.2 & Soil & SMA & Aspergillus sp. & - \\
IS-13 & Soil & SMA & Aspergillus sp. & - \\
$\mathbf{2 . 5}$ & Air & LB & Aspergillus sp. & - \\
$\mathbf{8 . 5}$ & Air & LB & Curvularia sp. & - \\
$\mathbf{7 . 3}$ & Air & LB & Aspergillus ochraceus* & MN782329 \\
$\mathbf{7 . 4}$ & Air & LB & Aspergillus melleus* & MN782331 \\
$\mathbf{8 . 2}$ & Air & LB & Fusarium sp. & - \\
$\mathbf{8 . 4}$ & Air & LB & Penicillium rolfsii* & MN782330 \\
\hline
\end{tabular}

NOTE: Selective means used for insulation: HSUC; SMA = Starch Milk Agar; LB = Luria Bertani. Molecular identification was performed only on the fungi indicated with “*”. Source: The Authors.

\subsection{Pilot Scale Fermentation}

Considering the potential of filamentous fungi as antimicrobial suppliers (Adpressa \& Loesgen, 2016), filamentous fungi isolated from the Amazonian environment were cultivated under different conditions in order to evaluate the most appropriate culture media and time for an antimicrobial screening program. The isolates were fermented in two distinct periods for antimicrobial potential determination and the choice of the evaluated nutritional conditions was based on the search for the expression of little explored metabolic pathways under normal fermentation conditions (Adpressa \& Loesgen, 2016). This is because, substantial changes in these conditions can promote real effects on the final metabolic profile (Ochi, 2016). The 
rotation scheme adopted in submerged crops and pre-inoculum of solid crops (pre-fermentation in YESD broth) was determined by the need for multiplication of the mycelial mass produced in each fermented group.

Regarding the yields obtained within each cultivation group (Fig. 1A), it was observed that the dry masses produced comparing the solid crops (rice and oats) did not present significant differences between the two evaluated periods (11 and 31 days). However, individually analyzed, some isolates increased the extract biomass in the 31-day oat substrate, when compared to the mass produced by the same fungus cultivated in rice. This increase in biomass occurred especially for TPP1.1, 8.4, 2.5 and 8.2 fungi grown on oat substrate during the 31 days of fermentation (data not shown).

Comparing the yield obtained in the solid cultivation rice (11 and 31 days) and Czapeck broth (14 and 21 days) (Fig. 1B), it was observed that there was no significant difference in relation to the masses produced $(\mathrm{p}=0.3432)$. ). However, individually analyzed, it was observed that the fungi 8.4, 8.2, TPP1.1, HSUC-6, 8.5 and 7.4 produced higher biomass of extracts when compared to the liquid culture (data not shown).

Figure 1. Comparison of yield of crude extracts produced in pilot scale crops.
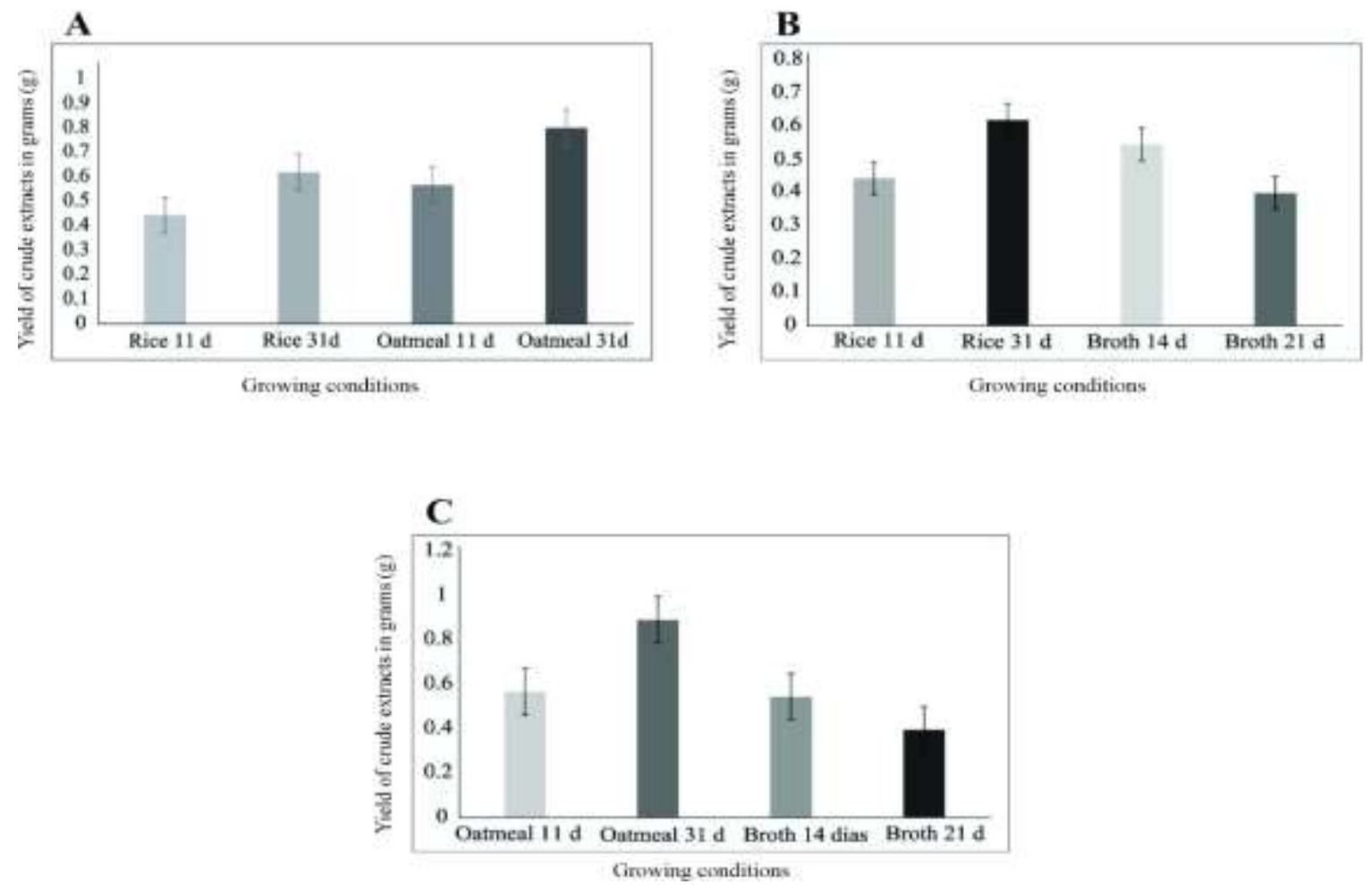

Figure 1A: Yield of crude extracts produced in rice and oat crops at 11 and 31 days of fermentation; Figure 1B: Yield of crude extracts produced in oat (11 and 31 days of fermentation) and broth (14 and 21 days of fermentation) crops; Figure 1C: Yield of crude extracts produced in rice (11 and 31 days of fermentation) and broth (14 and 21 days of fermentation) crops. Source: The Authors.

There were no differences in yields comparing solid oat crops (11 days) and liquid crops (14 days) of fermentation (p $=0.1267$ ). However, the 31-day cultivation on oat substrate produced a significantly higher mass than the 21-day broth cultivation $(\mathrm{p}=0.0422)$ (Fig. 1C), which was also observed by VanderMolen et al. (2013) where crops grown in solid media (especially oat cultivation) produced extracts with masses one to two orders of magnitude larger than the same fungus grown in liquid media. 


\subsection{Antimicrobial Activity of Raw Extracts}

The antimicrobial potential of extracts produced in different crops was evaluated. In each growing condition, moderate activity was observed against one or more strains tested. In particular, solid media extracts were active against Gramnegative $E$. coli bacteria, with inhibition halos up to $15 \mathrm{~mm}$ in diameter (Table 2).

In this study, eight strains of the genus Aspergillus sp. (IS-6, TPP1.1, TPP1.2, IS-13, 7.4, 7.3, 2.5 and IS-7) produced extracts with antimicrobial activity against $E$. coli and $S$. aureus in at least one of the evaluated solid media. In another study, it was observed that the cultivation of fungi of the genus Aspergillus sp. in solid rice medium, for example, it generates extracts with antimicrobial potential against E. coli, S. aureus, Bacillus subtilis, Proteus mirabilis and Malassezia furfur (Chagas et al., 2017). Indeed, solid fermentation allows the production of a range of bioactive compounds (Li et al., 2016) such as fusarialin produced by Fusarium sp., with inhibitory activity against $S$. aureus in rice, in the study by Tchoukoua et al. (2018).

Currently, solid crops have been used in the literature as an alternative for the exploitation of fungal metabolic chemiodiversity. This is because these nutritional sources may favor the production of compounds that are sometimes not biosynthesized in standard liquid medium cultures (Li et al., 2019). Compared to liquid cultures, solid cultures produce greater diversity of compounds with antimicrobial and antifungal potential (Özkaya et al., 2018; Yue et al., 2015; Hemphill et al., 2017; Wang et al., 2015).

The antimicrobial potential of extracts produced in solid crops compared to extracts produced in liquid crops is relatively attractive. In particular, the extract produced in oat cultivation by the fungus P. maximae (HSUC-6) was active against all strains tested, with inhibition halos ranging from 7-15 $\mathrm{mm}$ in diameter. In contrast, the same broth fungus did not produce potentially active extracts in the shortest fermentation periods (14 days). At 21 days of fermentation, the extracts were active against $E$. coli and Salmonella sp. with inhibition halos up to $15 \mathrm{~mm}$.

In the first fermentation periods in broth (14 days) only the fungus TPP1.2 produced extracts with antimicrobial activity. However, the longer broth cultivation period (21 days) allowed a larger portion of the cultivated fungi to produce active compounds (Table 2). 
Table 2. Antimicrobial activity of crude extracts produced under different fermentation conditions.

\begin{tabular}{|c|c|c|c|c|c|}
\hline \multirow[t]{2}{*}{ Fungus } & \multirow[t]{2}{*}{ Substrate } & \multirow{2}{*}{$\begin{array}{c}\text { Crude } \\
\text { Extract }\end{array}$} & \multicolumn{3}{|c|}{ Test microorganisms } \\
\hline & & & Escherichia coli & Salmonella sp. & Staphylococcus aureus \\
\hline \multirow{4}{*}{$I S-6$} & Rice & 31 days & - & - & + \\
\hline & Oatmeal & 31 days & + & - & + \\
\hline & Czapeck & 14 days & - & - & - \\
\hline & Broth & 21 days & ++ & - & - \\
\hline \multirow{5}{*}{ HSUC-6 } & Rice & 31 days & ++ & ++ & + \\
\hline & Oatmeal & 31 days & ++ & ++ & ++ \\
\hline & Czapeck & 14 days & - & - & - \\
\hline & Broth & 21 days & ++ & ++ & - \\
\hline & Rice & 31 days & + & + & + \\
\hline \multirow[t]{4}{*}{$T P P 1.1$} & Oatmeal & 31 days & ++ & ++ & ++ \\
\hline & Czapeck & 14 days & - & - & - \\
\hline & Broth & 21 days & + & + & + \\
\hline & Rice & 31 days & + & + & + \\
\hline \multirow[t]{4}{*}{ TPP1.2 } & Oatmeal & 31 days & + & + & + \\
\hline & Czapeck & 14 days & + & ++ & ++ \\
\hline & Broth & 21 days & ++ & ++ & ++ \\
\hline & Rice & 31 days & + & - & - \\
\hline \multirow[t]{4}{*}{$I S-13$} & Oatmeal & 31 days & ++ & ++ & ++ \\
\hline & Czapeck & 14 days & - & - & - \\
\hline & Broth & 21 days & ++ & ++ & + \\
\hline & Rice & 31 days & ++ & ++ & + \\
\hline \multirow[t]{4}{*}{7.4} & Oatmeal & 31 days & ++ & + & ++ \\
\hline & Czapeck & 14 days & - & - & - \\
\hline & Broth & 21 days & ++ & ++ & + \\
\hline & Rice & 31 days & + & + & ++ \\
\hline \multirow[t]{4}{*}{8.2} & Oatmeal & 31 days & - & + & + \\
\hline & Czapeck & 14 days & - & - & - \\
\hline & Broth & 21 days & - & + & - \\
\hline & Rice & 31 days & ++ & ++ & ++ \\
\hline \multirow[t]{3}{*}{7.3} & Oatmeal & 31 days & ++ & ++ & + \\
\hline & Czapeck & 14 days & - & - & - \\
\hline & Broth & 21 days & - & - & - \\
\hline \multirow{4}{*}{2.5} & Rice & 31 days & ++ & ++ & + \\
\hline & Oatmeal & 31 days & + & - & + \\
\hline & Czapeck & 14 days & - & - & - \\
\hline & Broth & 21 days & - & - & - \\
\hline \multirow{4}{*}{8.5} & Rice & 31 days & + & - & + \\
\hline & Oatmeal & 31 days & + & + & ++ \\
\hline & Czapeck & 14 days & - & - & - \\
\hline & Broth & 21 days & - & - & + \\
\hline \multirow{4}{*}{8.4} & Rice & 31 days & ++ & ++ & + \\
\hline & Oatmeal & 31 days & + & - & + \\
\hline & Czapeck & 14 days & - & - & - \\
\hline & Broth & 21 days & - & - & - \\
\hline \multirow{5}{*}{ IS-7 } & Rice & 31 days & - & - & ++ \\
\hline & Oatmeal & 31 days & + & ++ & + \\
\hline & Czapeck & 14 days & - & - & - \\
\hline & Broth & 21 days & ++ & + & - \\
\hline & Negative control & & - & - & - \\
\hline
\end{tabular}

NOTE: Inhibition halo diameter in millimeters $(\mathrm{mm})$, reported here as: $(-)$, no inhibition effect detected; (+), zone of inhibition between 7 $9 \mathrm{~mm}$ (weak inhibition); (++) between $10 \sim 15 \mathrm{~mm}$ (moderate inhibitory effect) (+++) between $15 \sim 20 \mathrm{~mm}$ (strong inhibitory effect). Source: The Authors. 


\subsection{Antimicrobial Activity of Fractions}

Methanolic crude extracts that showed antimicrobial activity were partitioned and fractional yields were analyzed indicating how much of the crude extract solubilized in the different solvents. Also, the degree of polarity of the extracts with antimicrobial potential was evidenced, according to table 3.

Among the four fractions evaluated for antimicrobial activity in rice cultivation, only the remaining fractions were active, in this case against E. coli and S. aureus. When tested the same fractions against Salmonella sp., the remaining fraction showed the highest antimicrobial potential.

Oat cultivation fractions, when tested against E. coli, showed that most of the antimicrobial activity occurred in the Remnant fraction $(\mathrm{p}=0.001175)$, with inhibition halos between $7-11 \mathrm{~mm}$ in diameter. Among the fractions obtained from oat cultivation tested against Salmonella sp., there was a prevalence of antimicrobial activity of the remaining fraction in relation

to the other fractions tested $(\mathrm{p}=0.0004619)$. In addition, the remaining fractions obtained from oat cultivation were also active against $S$. aureus (Table 3).

Table 3. Antimicrobial activity of fractions obtained from different cultures.

\begin{tabular}{|c|c|c|c|c|c|}
\hline \multirow[t]{2}{*}{ Code } & \multirow[t]{2}{*}{$\begin{array}{l}\text { Collection } \\
\text { Source }\end{array}$} & \multirow[t]{2}{*}{$\begin{array}{c}\text { Strain } \\
\text { Identification }\end{array}$} & \multicolumn{3}{|c|}{$\begin{array}{l}\text { Antimicrobial activity } \\
\text { (active fractions) }\end{array}$} \\
\hline & & & E. coli & Salmonella sp. & S. aureus \\
\hline HSUC-6 & Soil & Penicillium maximae* & $\begin{array}{c}\text { Ric Rem } \\
\text { OatRem } \\
\mathrm{C} 21^{\text {Hex/Chlo/Act/Rem }}\end{array}$ & $\begin{array}{l}\text { Ric Rem } \\
\text { OatRem } \\
\text { C } 21^{\text {Rem }}\end{array}$ & $\begin{array}{c}\text { Ric Rem } \\
\text { OatRem } \\
\mathrm{C} 21^{\text {Hex }} / \text { Chlo/Act/Rem }\end{array}$ \\
\hline IS-6 & Soil & Aspergillus sp. & $\begin{array}{c}\text { RicRem }^{\text {Rem }} \\
\text { Oat }^{\text {Hex/Chlo/Act/Rem }}\end{array}$ & $\begin{array}{l}\text { Ric Rem } \\
\text { Oat }{ }^{\text {Rem }}\end{array}$ & $\begin{array}{l}- \\
-\end{array}$ \\
\hline IS-7 & Soil & Aspergillus sp. & $\begin{array}{c}\text { Ric }{ }^{R e m} \\
\text { Oat }{ }^{R e m} \\
- \\
\end{array}$ & $\begin{array}{c}\mathrm{Ric}^{\mathrm{Rem}} \\
\text { Oat }{ }^{\mathrm{Hex}} / \mathrm{Chlo} / \mathrm{Act} \\
\mathrm{C} 21^{\text {Rem }}\end{array}$ & $\begin{array}{c}\text { Ric }^{\text {Rem }} \\
- \\
- \\
\end{array}$ \\
\hline TPP1.1 & Soil & Aspergillus sp. & $\begin{array}{c}\mathrm{Ric}^{\text {Rem }} \\
\text { Oat } \\
\text { C } 21^{\text {Chlom/Act }}\end{array}$ & $\begin{array}{c}\text { Ric }{ }^{\text {Rem }} \\
\text { Oat Rem } \\
\text { C2 } 21^{\text {Hex } / \text { Chlo/ActRem }}\end{array}$ & $\begin{array}{l}\text { Ric Rem } \\
\text { Oat }{ }^{\text {Rem }} \\
-\end{array}$ \\
\hline TPP1.2 & Soil & Aspergillus sp. & $\begin{array}{c}\text { C14 Rem } \\
\text { C21 Act } \\
-\end{array}$ & $\begin{array}{c}\mathrm{C} 14 \\
\text { Hex/Chlo/Act/Rem } \\
\text { C21 Rem } \\
-\end{array}$ & $\begin{array}{l}\text { Ric } \\
\text { C14em } 14^{\text {Rem }} \\
\text { C2 } 21^{\text {Rem }}\end{array}$ \\
\hline IS-13 & Soil & Aspergillus sp. & $\begin{array}{l}\text { Ric Rem } \\
\text { Oat Rem } \\
\text { C } 21^{\text {Rem }}\end{array}$ & $\begin{array}{c}\text { Oat Rem } \\
\text { C2 } 21^{\text {Rem }} \\
-\end{array}$ & $\begin{array}{c}\text { Oat } \\
\text { C2 } 21^{\text {Rem }} \\
-\end{array}$ \\
\hline 2.5 & Air & Aspergillus sp. & $\begin{array}{l}\text { Ric Rem } \\
\text { Oat Rem }\end{array}$ & $\begin{array}{c}\text { Oat } \\
-\end{array}$ & $\begin{array}{l}\text { Ric Rem } \\
\text { Oat }{ }^{R e m}\end{array}$ \\
\hline 8.5 & Air & Curvularia sp. & $\begin{array}{c}\text { OatRem } \\
-\end{array}$ & $\begin{array}{c}\text { Oat }{ }^{\text {Rem }} \\
\text { C21 ActRem }\end{array}$ & $\begin{array}{l}\text { Oat } \\
\text { C } 21^{\text {Rem }}\end{array}$ \\
\hline 7.3 & Air & Aspergillus ochraceus* & $\begin{array}{c}\text { Ric }^{\text {Rem }} \\
\text { Oat }{ }^{\mathrm{Hex} \text { Chlo/Rem }}\end{array}$ & $\begin{array}{c}\text { Oat } \\
- \\
\end{array}$ & $\begin{array}{l}\text { Ric Rem } \\
\text { Oat Rem }\end{array}$ \\
\hline 7.4 & Air & Aspergillus melleus* & $\begin{array}{c}\text { Ric }^{\text {Rem }} \\
\text { Oat }^{\text {Hex/Rem }} \\
-\end{array}$ & $\begin{array}{c}\text { Ric }{ }^{\text {Rem }} \\
\text { OatRem } \\
\text { C2 } 21^{\text {Hex } / \text { Chlo/ActRem }}\end{array}$ & $\begin{array}{c}\text { Ric } \\
- \\
- \\
\end{array}$ \\
\hline 8.2 & Air & Fusarium $\mathrm{sp}$. & - & C21 Act Rem & Oat $t^{R e m}$ \\
\hline 8.4 & Air & Penicillium rolfsii* & $\begin{array}{c}\text { Ric }{ }^{\text {Rem }} \\
\text { Oat }{ }^{\text {Rem }} \\
\text { C2 } 21^{\text {Hex } / \text { Chlo/Act }}\end{array}$ & $\begin{array}{c}\mathrm{Ric}^{\mathrm{He} / \mathrm{Chlo} / \mathrm{Act} / \mathrm{Rem}} \\
\mathrm{Oat} \text { Rem } \\
\mathrm{C} 21^{\text {Chlo/Act }}\end{array}$ & $\begin{array}{c}\text { Oat }^{\text {Rem }} \\
\mathrm{C} 21^{\mathrm{Hex} / \mathrm{Chlo}} \\
-\end{array}$ \\
\hline
\end{tabular}

NOTE: Cultivation substrates and their active fractions are indicated by acronyms: $*$ Ric $=$ Rice solid substrate; $*$ Oat $=$ Oat solid substrate; $*$ C14 and C21 = 14 and 21 day Czapeck Dox Broth; $*$ Hex = Fraction hexane; * Chlo = Chloroform fraction; Act $=$ Fraction of ethyl acetate;

$*$ Rem $=$ Remaining Fraction. Source: The Authors. 
The fractions obtained from broth cultures (14 and 21 days) were active in all fractions tested, with no prevalence of antimicrobial activity for a particular fraction. Moreover, when evaluating the yield of the fractions obtained from the broth cultivation, for the lower polarity fractions the yield was lower than for the higher polarity fractions when compared to the results with solid cultivation, suggesting that in the broth fermentation there was a lower production of nonpolar compounds.

In contrast, in oat cultivation, larger amounts of nonpolar compounds were produced when compared to broth cultivars, whereas the hexane fraction, although not showing antimicrobial activity, had significantly higher yield $(\mathrm{p}=0.0132$ ) when compared to the others. fractions (data not shown). This was also observed in the study by VanderMolen et al. (2013), where the authors mention that, after degreasing solid extracts from oat cultivation, there was a reduction in total dry mass, since hexane washing eliminated some common and unwanted metabolites (eg fatty acids). Thus, although the yield obtained in oat cultivation is relatively higher than that produced in broth cultivation, part of this mass is represented by (undesirable) nonpolar compounds, suggesting the need for refinement in the purification processes of the compounds of interest (VanderMolen et al., 2013).

\subsection{Complexity of Pilot Scale Fractions}

The remaining fractions obtained from the pilot crop (rice, oats and Czapeck broth) were analyzed by UV - Vis absorbance spectrophotometer and showed differences regarding the complexity of the extracts produced between different crops (Figure 2).

Figure 2. Complexity of extracts obtained under different fermentation conditions.

A

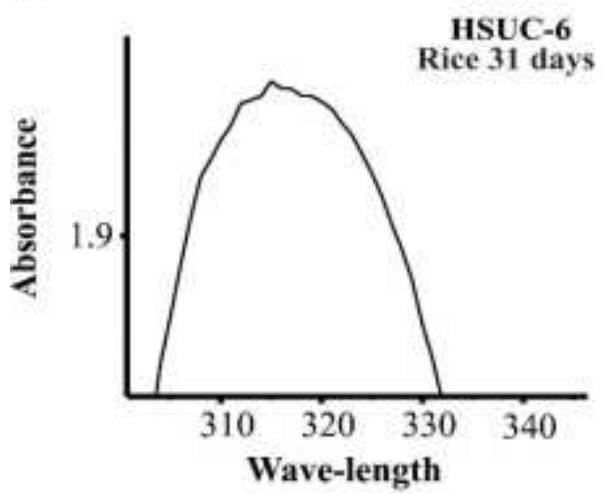

C

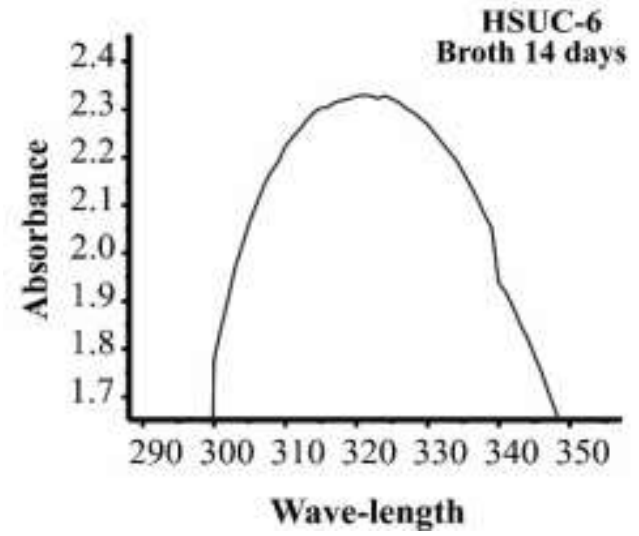

B

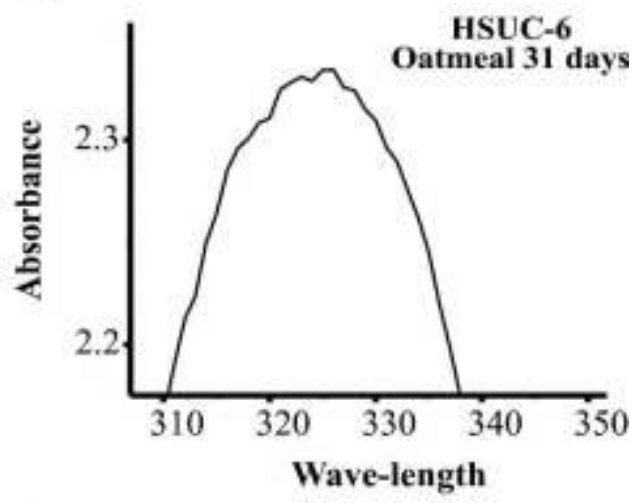

D

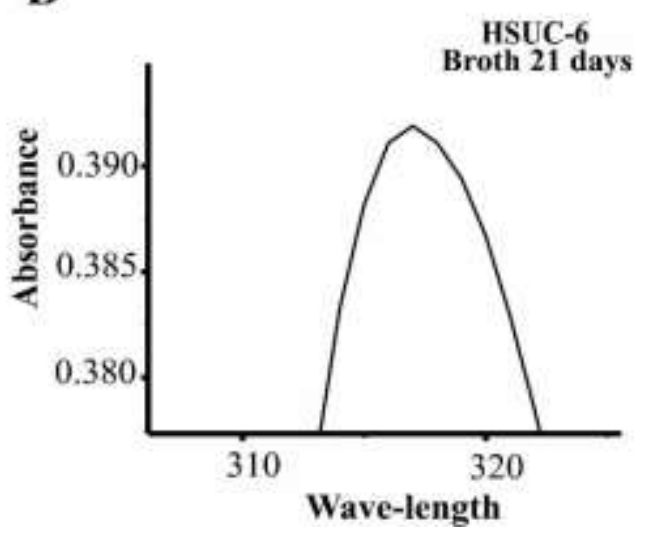

Fig 2A: UV spectrum of HSUC-6 extract produced in rice at 31 days of fermentation. 2B: UV spectrum of oat-produced HSUC-6 extract within 31 days of fermentation. 2C: UV spectrum of broth HSUC-6 extract produced in 21 days of fermentation. 2D: UV spectrum of broth HSUC-6 extract on 21 days of fermentation. Source: The Authors. 
The UV spectra of HSUC-6 (Penicillium maximae) extracts indicated that different substances may have been produced when the fungus was grown on solid media (oats and rice), as shown in Figure 2, because the UV spectra of solid crops show peaks. not observed in the UV spectra of the liquid cultures, presuming a greater complexity of the mixture. The study by Gao et al. (2012) reinforces this idea by evaluating HPLC chromatograms of extracts produced by Penicillium commune QDS-17 fungus, where it was observed that the fungus produced nine new compounds only when grown on solid substrate, and this production of a wider range of compounds. was assumed from the higher number of peaks when compared to liquid cultures.

This was also observed in the comparative study of the metabolic profile of the fungus Aspergillus carneus associated with sea sponge (Agelas oroides). The fungus was cultivated in solid medium rice with sea salt, rice without sea salt and in modified Czapeck broth. Of the three new isolated compounds, isopropylchaetominin was observed in the three culture media used. Isoterrelumamide A was produced only when the fungus was grown in modified Czapeck and 5'-epi-averufanin was isolated only when the fungi were grown in solid rice with or without sea salt (Özkaya et al., 2018), adding to the idea that the fermentation condition may alter the metabolic pathway of a given microorganism in a culture environment, favoring the production of new bioactive compounds (Romano, Jackson, Patry \& Dobson, 2018).

\subsection{Large Scale Fermentation}

Large-scale oat yields obtained after 39 days of fermentation were compared with oat-crop yields at 11 and 31 days of smaller-scale fermentation (Figure 3) by dividing the yield obtained (in grams) by the amount of substrate used in the fermentation (in grams). The mass produced in the 39 days of cultivation was considerably larger than the one produced in smaller scale $(\mathrm{p}=0,01171)$. However, this condition seems to depend directly on the metabolism of each fungus grown on this substrate.

Figure 3. Comparison of different fermentation scales in oat substrate $(\mathrm{p}=0.01171)$.

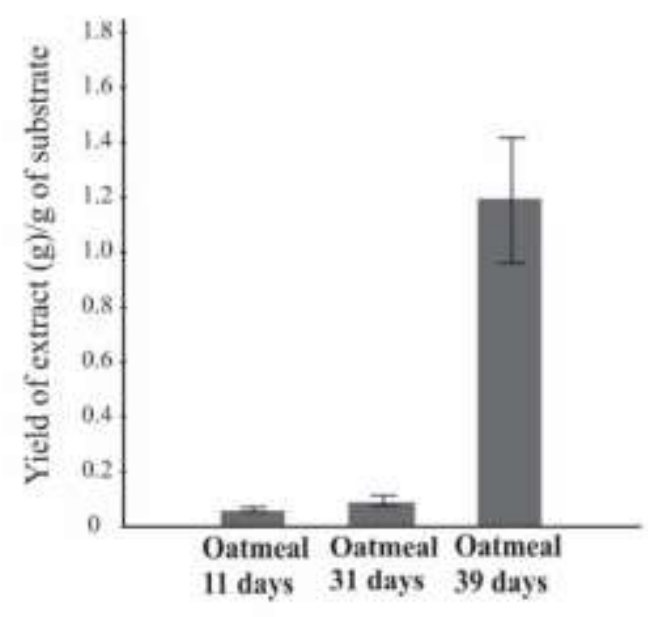

Source: The Authors.

\subsection{Antimicrobial Activity of Partially Purified Fractions}

The HSUC-6 and IS-9 extracts obtained from large-scale solid cultivation were partially purified generating fractions, such as which were tested for antimicrobial activity (Table 4). 
The three partially purified fractions of the HSUC-6 extract (produced by Penicillium maximae) were active against at least two of the three microorganisms evaluated (E.coli, Salmonella sp. and S. aureus). It is worth noting that the fungus $P$. maximae is of great importance as it is little explored due to its recent isolation.

Table 4. Antimicrobial potential of partially purified fractions.

\begin{tabular}{c|ccc}
\hline Purified Fractions & Escherichia coli & Salmonella sp. & Staphylococcus aureus \\
\hline IS-9 SOL P.C & $8,5 \mathrm{~mm}$ & $7,5 \mathrm{~mm}$ & - \\
F5IS & $8,6 \mathrm{~mm}$ & $8,0 \mathrm{~mm}$ & - \\
F7IS & $8,3 \mathrm{~mm}$ & $9,1 \mathrm{~mm}$ & $7,1 \mathrm{~mm}$ \\
HSUC-6 FIL LIQ 1 & $7,1 \mathrm{~mm}$ & $7,2 \mathrm{~mm}$ & $7,1 \mathrm{~mm}$ \\
HSUC-6 PAP FIL 1 & $7,4 \mathrm{~mm}$ & $7,4 \mathrm{~mm}$ & $7,2 \mathrm{~mm}$ \\
HSUC-6 PAP FIL 2 & $7.8 \mathrm{~mm}$ & - & $7,0 \mathrm{~mm}$ \\
HSUC-6 PAP FIL 3 & $8,0 \mathrm{~mm}$ & $8,1 \mathrm{~mm}$ & $7,1 \mathrm{~mm}$ \\
\hline
\end{tabular}

Source: The Authors.

Of the partially purified fractions of the IS-9 extract (produced by Fusarium oxysporum), three fractions showed antimicrobial activity, especially against E.coli and Salmonella sp.. In the study by Tchoukoua et al. (2018), in turn, the cultivation of fungi of the genus Fusarium isolated from the surface of insects in solid substrate yielded the production of three new compounds (3-epi-fusarielin H, 3-O-methyl-fusarielin $\mathrm{H}$ and 3-O- methyl-epi-fusarielin $\mathrm{H}$ ) and two other known fusarielin analogues (Fusarielin F and G) of which showed antimicrobial potential against S. aureus NBCR 13276.

Furthermore, as active fractions produced by large-scale cultivation were tested for antimicrobial activity using the Bioautography technique, as shown in Figure 4.

Figure 4. Evaluation of antimicrobial potential of partially purified fractions produced by P. maximae.

A

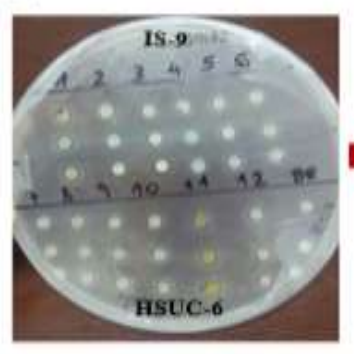

B

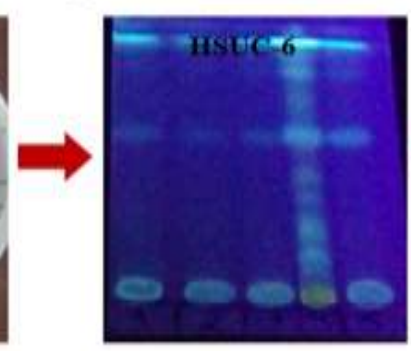

C

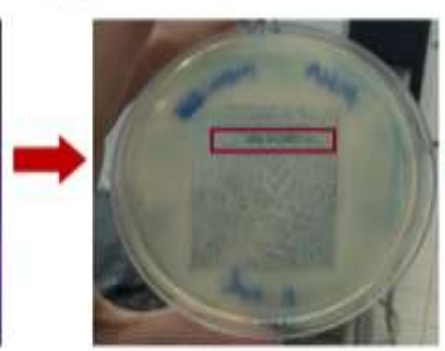

D

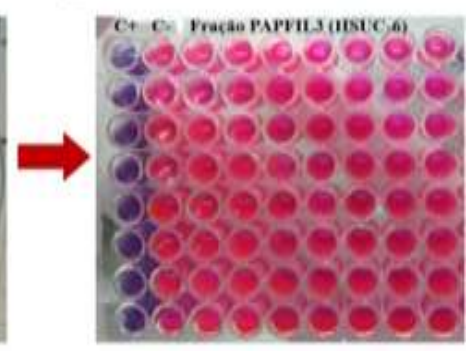

Figure 4A: Antimicrobial activity test of HSUC-6 fractions after disk diffusion partition. Figure 4B: Thin Layer Chromatography of partially purified fractions. Figure 4C: Bioautography of HSUC-6 fractions against inhibition-spotted E. coli $(\mathrm{Rf}=0.80)$. Figure 4D: Minimum inhibitory concentration test of HSUC-6 PAP Fil3 fraction of $P$. maximae against $E$. coli at concentrations; 500, 250, 125, 62.5, 31.2, 15.6, 7.8 and $3.9 \mu \mathrm{g} / \mathrm{mL}$. Source: The Authors.

The active fractions (Figure 4A) of the IS-9 (Fusarium oxysporum) and HSUC-6 (Penicillium maximae) were tested for antimicrobial activity by bioautography. Activity was observed from one of the bands of the HSUC-6 PAP Fil3 fraction of $P$. maximae against E. coli (Figure 4C). However, in the MIC test, the fraction was not active against $E$. coli at any of the concentrations tested (Figure 4D). Presumably the bioactive compounds were in insufficient concentration in the fraction tested to evidence the antimicrobial activity in this test.

\section{Conclusion}

In this study, although preliminary, it was observed that solid media appear to provide a more diverse range of antimicrobial active secondary metabolites when compared to liquid cultures. In addition, solid crops can guarantee sufficient 
extract yield for the isolation of the bioactive compounds of interest. However, in liquid cultures extracts with smaller amounts of nonpolar compounds are produced, facilitating later antimicrobial isolation steps.

In the antimicrobial screening program of this working group, considering the problem of rediscovery in this area and based on the results observed here, solid cultivation in rice medium and static fermentation for 39 days at room temperature will be employed in subsequent works.

For future work, the cultivation of filamentous fungi under static fermentation conditions for 39 days is suggested, which may be promising for obtaining bioactive compounds with antibacterial potential. In addition, it is necessary to search for strategies that optimize the conditions for purification and isolation of bioactive compounds, in order to facilitate the subsequent stages of analysis.

\section{Acknowledgments}

The authors thank the Higher Education Personal Improvement Coordination (CAPES) and the PROCAD Amazônia Program 2018 .

\section{References}

Adpressa, D., \& Loesgen, S. (2016). Bioprospecting Chemical Diversity and Bioactivity in a Marine Derived Aspergillus terreus. Chemistry \& Biodiversity, 13 (2), 253-259.

Atanasov, A. G., Zotchev, S. B., Dirsch, V. M., International Natural Product Sciences Taskforce, \& Supuran, C. T. (2021). Natural products in drug discovery: advances and opportunities. Nature reviews Drug discovery, 20(3), 200-216.

Awaad, A. S., Nabilah, A. J. A., \& Zain, M. E. (2012). New Antifungal Compounds from Aspergillus terreus Isolated from Desert Soil. Phytotherapy Research, 26 (12), 1872-1877.

Azerang, P., Khalaj, V., Kobarfard, F., Owlia, P., Sardari, S., \& Shahidi, S. (2019). Molecular Characterization of a Fungus Producing Membrane Active Metabolite and Analysis of the Produced Secondary Metabolite. Iran Biomedical Journal, 23 (2), 121-8.

Bérdy, J. (2012). Thoughts and facts about antibiotics: Where we are now and where we are heading. The Journal of Antibiotics, 65 (8), $441-441$.

Chagas, M. B. O., Prazeres, S. I., Nascimento, S. L.C., Correia, M. T. D. S., Magali, de A. J., Cavalcanti, M. D. S., \& Lima, V. L. M. (2017). Antimicrobial Activity of Cultivable Endophytic Fungi Associated with Hancornia Speciosa Gomes Bark. Open Microbiology Journal, 11, $179-188$.

Cruz, A. L., Souza, F. S. de., \& Abegg, M. A. (2019). Anti-Candida and anti-quorum sensing activity of airborne microorganisms detected by a rapid method. Revista da Sociedade Brasileira de Medicina Tropical, 52 (0).

Dayanidhi, D. L., Thomas, B. C., Osterberg, J. S., Vuong, M., Vargas, G., Kwartler, S. K., Schmaltz, E., Dunphy-Daly, M. M., Schultz, T. F., Rittschof, D., Eward, W. C., Roy, C., \& Somarelli, J. A. (2021). Exploring the Diversity of the Marine Environment for New Anti-cancer Compounds. Frontiers in Marine Science, 1184 (7), 2296-7745.

Dewanjee, S., Gangopadhyay, M., Bhattacharya, N., Khanra, R., \& Dua, T. K. (2015). Bioautography and its scope in the field of natural product chemistry. Journal of Pharmaceutical Analysis, 5 (2), 75-84.

Du, L., King, J. B., Morrow, B. H., Shen, J. K., Miller, A. N., \& Cichewicz, R. H. (2012). Diarylcyclopentendione metabolite obtained from a Preussia typharum isolate procured using an unconventional cultivation approach. Journal of Natural Products, 75 (10), $1819-23$.

Etame, R. M. E., Mouokeu, R. S., Poundeu, F. S. M., Voukeng, I. K., Cidjeu, C. L. P., Tiabou, A. T., Yaya, A. J. G., Ngane, R. A. N., Kuiate, J. R., \& Etoa, F. X. (2019). Effect of fractioning on antibacterial activity of n-butanol fraction from Enantia chlorantha stem bark metanol extract. BMC Complementary and Alternative Medicine, 19 (1), 56.

Fleming, H. P., Etchells, J. L., \& Costilow, R. N. (1975). Microbial inhibition by an isolate of pediococcus from cucumber brines. Applied microbiology, 30(6), 1040-1042.

Gao, S. S., Shang, Z., Li, X. M., Li, C. S., Cui, C. M., \& Wang, B. G. (2012). Secondary Metabolites Produced by Solid Fermentation of the Marine-Derived Fungus Penicillium commune QSD-17. Bioscience Biotechnology Biochemistry, 76(2), 358-360.

Gomes, C. C., Pinto, L. C. C., Victor, F. L., da Silva, E. A. B., Ribeiro, A. de A., Saqruis, M. I. de M., \& Camões, I. C. G. (2015). Aspergillus in endodontic infection near the maxillary sinus. Brazilian Journal of Otorhinolaryngology, 81 (5), 527-532.

Hemphill, C. F. P., Sureechatchaiyan, P., Kassack, M. U., Orfali, R. S., Lin, W., Daletos, G., \& Proksch, P. (2017). OSMAC approach leads to new fusarielin metabolites from Fusarium tricinctum. The Journal of Antibiotics, 70 (6), 726-732. 
Katoch, M., Phull, S., Vaid, S., \& Singh, S. (2017). Diversity, Phylogeny, anticancer and antimicrobial potential of fungal endophytes associated with Monarda citriodora L. BMC Microbiology, 17 (1).

Li, W., Ding, L., Wang, N., Xu, J., Zhang, W., Zhang, B., \& Jin, H. (2019). Isolation and Characterization of Two New Metabolites from the Sponge-Derived Fungus Aspergillus sp. LS34 by OSMAC Approach. Marine Drugs, 17 (5), 283.

Li, Y. F., Wu, X. B., Niaz, S. I., Zhang, L. H., Huang, Z. J., Lin, Y. C., Li, J., \& Liu, L. (2016). Effect of culture conditions on metabolites produced by the crinoid-derived fungus Aspergillus ruber 1017. Natural Product Research, 31 (11), 1299-1304.

Lotfy, M. M., Sayed, A. M., AboulMagd, A. M, Hassan, H. M., El Amir, D., Abouzid, S. F., El-Gendy, A. O., Rateb, M. E., Abdelmohsen, R. U., Alhadrami, H., \& Mohammed, R. (2021). Metabolomic profiling, biological evaluation of Aspergillus awamori, the river Nile-derived fungus using epigenetic and OSMAC approaches. Royal Society and Chemistry, 11, 6709.

Noumi, E., Merghni, A., M Alreshidi, M., Haddad, O., Akmadar, G., De Martino, L., Mastouri, M., Ceylan, O., Snoussi, M., Al-Sieni, A., \& De Feo, V. (2018). Chromobacterium violaceum and Pseudomonas aeruginosa PAO1: Models for Evaluating Anti-Quorum Sensing Activity of Melaleuca alternifolia Essential Oil and Its Main Component Terpinen-4-ol. Molecules, 23 (10).

Ochi, K. (2016). Insights into microbial cryptic gene activation and strain improvement: principle, application and technical aspects. Journal of Antibiotics, 70 (1), 25-40.

Özkaya, F. C., Ebrahim, W., El-Neketi, M., Tansel, T. T, Kalscheuer, R., Muller, W. E. G., Guo, Z., Zou, K., Liu, Z. \& Proksch, P. (2018). Induction of new metabolites from sponge-associated fungus Aspergillus carneus by OSMAC approach. Fitoterapia, 131:9-14.

Palma Esposito, F., Giugliano, R., Della Sala, G., Vitale, G. A., Buonocore, C., Ausuri, J., Galasso, C., Coppola, D., Franci, G., Galdiero, M., \& de Pascale, D. (2021). Combining OSMAC Approach and Untargeted Metabolomics for the Identification of New Glycolipids with Potent Antiviral Activity Produced by a Marine Rhodococcus. International journal of molecular sciences, 22(16), 9055.

Pan, R., Bai, X., Chen, J., Zhang, H., \& Wang, H. (2019). Exploring Structural Diversity of Microbe Secondary Metabolites Using OSMAC Strategy: A Literature Review. Frontiers in Microbiology, 10, 294.

Raghava Rao, K. V., Mani, P., Satyanarayana, B., \& Raghava Rao, T. (2017). Purification and structural elucidation of three bioactive compounds isolated from Streptomyces coelicoflavus BC 01 and their biological activity. Biotech, 7 (1), 24.

Rani, R., Sharma, D., Chaturvedi, M., \& Yadav, J. P. (2017). Antibacterial activity of twenty different endophytic fungi isolated from Calotropis procera and time kill assay. Clinical Microbiology, 6 (3), 280.

Romano, S., Jackson, S. A., Patry, S., \& Dobson, A. D. W. (2018). Extending the "One Strain Many Compounds" (OSMAC) Principle to Marine Microorganisms. Marine Drugs, 16 (7).

Sanchez, J. F., \& Wang, C. C. (2012). The chemical identification and analysis of Aspergillus nidulans secondary metabolites. Methods of Molecluar Biology, 944, 97-109.

Scopel, M., Mothes, B., Lerner, C. B., Henriques, A. T., Macedo, A. J., \& Abraham, W. R. (2017). Arvoredol—An unusual chlorinated and biofilm inhibiting polyketide from a marine Penicillium sp. of the Brazilian coast. Phytochemistry Letters, 20, 73-76.

Silveira, L. M., Olea, R. S. G., Mesquita, J. M., Cruz, A. L. N., \& Mendes, J. C. (2009). Metodologias de atividade antimicrobiana aplicadas a extratos de plantas: comparação entre duas técnicas de ágar difusão. Revista Brasileira de Farmácia, 90 (2) 2, 124-128.

Tchoukoua, A., Hasegawa, R., Hendracipta, K. A., Sato, S., Koseki, T., \& Shiono, Y. (2018). Structure elucidation of new fusarielins from Fusarium sp. and their antimicrobial activity. Magnetic Resonance Chemistry, 56 (1), 32-36.

Tonial, F., Maia, B. H. L. N. S., Gomes-Figueiredo, J. A., Sobottke, A. M., Bertol, C. D., Nepel, A., Savi, D. C., Vicente, V. A., Gomes, R. R., \& Glienke, C. (2015). Influence of Culturing Conditions on Bioprospecting and the Antimicrobial Potential of Endophytic Fungi from Schinus terebinthifolius. Current Microbiology, 72 (2), 173-183.

VanderMolen, K. M., Raja, H. A., El-Elimat, T., \& Oberlies, N. H. (2013). Evaluation of culture media for the production of secondary metabolites in a natural products screening program. AMB Express, 3(1), 71.

Wang, B., Park, E. M., King, J. B., Mattes, A. O., Nimmo, S. L., Clendinen, C., Edison, A. S., Anklin, C., \& Cichewicz, R. H. (2015). Transferring Fungi to a Deuterium-Enriched Medium Results in Assorted, Conditional Changes in Secondary Metabolite Production. Journal of Natural Products, 78 (6), $1415-21$.

Yue, Y., Yu, H., Li, R., Xing, R., Liu, S., \& Li, P. (2015). Exploring the Antibacterial and Antifungal Potential of Jellyfish-Associated Marine Fungi by Cultivation-Dependent Approaches. Plos One, 10 (12), e0144394.

Zutz, C., Bacher, M., Parich, A., Kluger, B., Gacek- Matthews, A., Schuhmacher, R., Wagner, M., Rychli, K., \& Strauss, J. (2016). Valproic Acid Induces Antimicrobial Compound Production in Doratomyces microspores. Frontiers in Microbiology, 7, 510. 